\title{
Analysis of Medicine Bow-Laramie River Drainage Divide Using Topographic Map Interpretation Techniques, Southeastern Wyoming, USA
}

\author{
Eric Clausen (1) \\ Jenkintown, PA, USA \\ Email:eric2clausen@gmail.com
}

How to cite this paper: Clausen, E. (2020) Analysis of Medicine Bow-Laramie River Drainage Divide Using Topographic Map Interpretation Techniques, Southeastern Wyoming, USA. Open Journal of Geology, 10, 741-759.

https://doi.org/10.4236/ojg.2020.107033

Received: July 3, 2020

Accepted: July 24, 2020

Published: July 27, 2020

Copyright (อ 2020 by author(s) and Scientific Research Publishing Inc. This work is licensed under the Creative Commons Attribution International License (CC BY 4.0).

http://creativecommons.org/licenses/by/4.0/ (c) (i) Open Access

\begin{abstract}
Detailed topographic maps provide much of the information needed to understand how drainage divides like the southeast Wyoming Medicine Bow River-Laramie River drainage divide originated. Topographic map evidence for each Medicine Bow-Laramie River drainage divide segment is here described and analyzed first using a commonly published interpretation (accepted paradigm) in which drainage routes developed on a surface of now mostly absent Oligocene and Miocene sediments that previous investigators have hypothesized to have once filled the Laramie Basin and to have also buried (or partially buried) the surrounding Laramie and Medicine Bow Mountains. Second, the same map evidence is analyzed using a recently proposed interpretation (new paradigm) in which massive and prolonged floods flowed across Wyoming as the Laramie and Medicine Bow Mountains began to be uplifted and as the southeast-oriented North Platte River valley eroded headward along the rising Laramie Mountains northeast flank. Low points along the drainage divide (referred to as divide crossings) are interpreted to be places where water once flowed across the drainage divide with the drainage divide being formed when capture events diverted the water in other directions. Valleys leading away from divide crossings are used to determine the nature of observed capture events, many of which are difficult or impossible to explain from the accepted paradigm perspective, but which are consistent with the mountain uplift, headward erosion of deeper valleys, and/or draining of floodwaters trapped in the Laramie Basin as the new paradigm predicts. However, the new paradigm requires a North American continental ice sheet heavy enough to raise entire regions and mountain ranges as massive and prolonged meltwater floods flowed across them, something the accepted pa-
\end{abstract}


radigm does not recognize.

\section{Keywords}

Divide Crossing, Geomorphology, Laramie Basin, Medicine Bow Mountains, North Platte River

\section{Introduction}

\subsection{Statement of the Problem}

How does drainage divide form? Bonnet [[1], p. 766], who studied drainage divides in laboratory settings suggests, "When associated with an orographic effect, drainage divide delineates domains where differences in precipitation and hydrologic regimes may directly influence erosional processes that shape the topography." But, in natural settings drainage divides often cross precipitation and hydrologic regimes and can begin in high mountain ranges and cross mountain-enclosed basins before entering and ending in other mountain ranges. Such drainage divides do not delineate precipitation and hydrologic regimes differences or influence erosional processes. One such drainage divide is the southeast Wyoming Medicine Bow-Laramie River drainage divide shown in Figure 1, which at its southwest end begins at Medicine Bow Peak (southeast Wyoming's highest point) as a triple drainage divide with the north-oriented North Platte River drainage basin (to the southwest). As the drainage divide progresses northeastward it crosses abandoned valleys as it descends approximately 1500 meters to cross the Laramie Basin floor before rising more than 500 meters into the Laramie Mountains where it meets the southeast-oriented North Platte River drainage basin (note in Figure 1 how the North Platte River in central Wyoming turns from flowing in a north direction to flow in a southeast direction).

Medicine Bow Peak (elevation 3652 meters) which is at the Medicine Bow-Laramie River drainage divide southwest end is a divide junction summit of the type Spotila [2] describes, where the Medicine Bow, Laramie, and north-oriented North Platte River drainage basins all meet. The Medicine Bow-Laramie River drainage divide northeast end is also a hilltop triple drainage divide, but at an elevation of about 2631 meters is just one of many Laramie Range hilltops with similar elevations. Between its two ends the Medicine Bow-Laramie River drainage divide is not always an identifiable ridge. In the Laramie Mountains the south-oriented North Laramie River has beheaded southwest-oriented Medicine Bow River tributary valleys while in the Medicine Bow Mountains a 200-meter deep gap between Medicine Bow Peak and Browns Peak links north-oriented Medicine Bow River headwaters with a south-oriented North Fork Little Laramie River tributary and southwest oriented South French Creek headwaters (with French Creek flowing to the north-oriented North Platte River as a barbed tributary). Between the Medicine Bow and Laramie Mountains the Medicine 
Bow-Laramie River drainage divide crosses Laramie Basin floor regions described by Mears [[3], p. 426] as having "a complex history of stream captures involving three streams that formerly flowed northeastward from the Medicine Bow Mountains across the Laramie Basin and Laramie Mountains.”

The Medicine Bow-Laramie River drainage divide shows no evidence of ever having migrated as laboratory and numerical landscape evolution models and simulations such as those done by Bonnet [1], Whipple et al. [4], Pelletier [5], Scherler and Schwanghart [6] and others sometimes suggest. Instead the detailed topographic maps show abandoned valleys cross the Medicine Bow-Laramie River drainage divide not only on the Laramie Basin floor, but also in the mountains at both ends. There is a major disconnect between drainage divides when observed in nature or on the detailed topographic maps and drainage divides when described in laboratory models or in numerical models and simulations. Detailed topographic maps provide what is probably the easiest and most efficient way to investigate actual drainage divides, yet are rarely used to do so. Detailed topographic maps show drainage divide locations and features, such as low points or abandoned valleys where water once crossed the drainage divides, and topographic map interpretation techniques permit drainage divide origins to be determined. This paper illustrates how detailed topographic maps and topographic map interpretation techniques can be used to determine the Medicine Bow-Laramie River drainage divide origin.

\subsection{Geographic Setting}

Study region geographic features are seen in Figure 1 and include the Medicine Bow (MB in Figure 1) and Laramie Mountains (LM) with the Medicine Bow Mountains extending in a north-northwest direction from northern Colorado into southern Wyoming. Near the Medicine Bow Mountains northern end is a southwest-to-northeast ridge of high peaks known as the Snowy Range. The Laramie Mountains are a northern extension of the Colorado Front Range and extend from northern Colorado in a north direction before turning in a northwestward direction to end in central Wyoming. The Medicine Bow and Laramie Mountains partially enclose the high elevation Laramie Basin (LB), but leave an opening to the northwest and west. All study region drainage flows to the North Platte River $(\mathrm{N})$, which begins in northcentral Colorado in a mountain enclosed basin known as North Park (west of the Medicine Bow Mountains). From North Park the North Platte River flows in a north-northwest direction and south-oriented streams flow as barbed tributaries to it from the Medicine Bow Mountains. Once in Wyoming the North Platte River flows in north and then northeast directions and after cutting across the Laramie Mountains northwest end turns in an east and then southeast direction to flow along the Laramie Mountains northeast flank and into western Nebraska (where it joins the South Platte River to form the Platte River with its water eventually reaching the Missouri and Mississippi Rivers and the Gulf of Mexico). Clausen 
[7] described north-oriented streams that start as south-oriented streams and then make U-turns to flow across the northern Laramie Mountains to join that east- and southeast-oriented North Platte River segment.

The Laramie River (L) begins in northern Colorado and its headwaters flow northward on the Medicine Bow Mountains east side beginning in what Bolyard [[8], p. 131] refers to as a north-south lineament that crosses the east-west continental divide and that links north-oriented Laramie River headwaters (flowing to the Gulf of Mexico) with south-oriented Colorado River headwaters (flowing to the Pacific Ocean). Clausen [9] suggests that while the region and mountains were being uplifted immense quantities of water flowed in south directions on either side of the rising Medicine Bow Mountains along the north-oriented Laramie and North Platte River alignments and into an actively eroding Colorado River headwaters valley and then when mountain uplift blocked south-oriented flow to the Colorado River the Laramie River flow direction was reversed with south-oriented flow still moving on the North Platte River alignment being forced to use what is now the west- and northwest-oriented Michigan River valley, Cameron Pass, and a Joe Wright Creek valley segment to make a U-turn around the Medicine Bow Mountains south end and then to flow in a north direction into the Laramie Basin. Today several south-oriented drainage systems flow from the Wyoming Medicine Bow Mountains to the north-oriented Laramie River and suggest a south-oriented drainage system once existed. McCallum [[10], p. 69] suggested the south-oriented drainage system existed during the late Eocene and/or earliest Oligocene and that by late Miocene the north-oriented drainage had developed.

Today the Laramie River after flowing in a north direction almost to where the Laramie Mountains change from being oriented in a north-to-south to a southeast-to-northwest direction makes an abrupt turn to flow in an east (and later northeast) direction to enter an anastomosing complex of bedrock-walled canyons described by Clausen [11] that cross the Laramie Mountains and to join the southeast-oriented North Platte River. Interestingly the North Laramie River flows in a south direction from the Laramie Mountains toward the Laramie River abrupt turn, but also abruptly turns in a northeast direction to cross the Laramie Mountains in its own canyon before joining the Laramie River. Many previous investigators attribute the Laramie River canyon to superposition (they rarely mention the diverging and converging bedrock-walled canyon complex or the separate North Laramie River canyon). For example, Eckerle [[12], p. 6] states the Laramie River's "deep canyon [is] incised into the Precambrian basement complex ... [and] is the result of superposition from overlapping Tertiary basin fill. Sediments once filled the [Laramie] basin and covered the mountain range." In contrast, Clausen [11] attributes the east-oriented anastomosing channel complex (which includes the northeast-oriented North Laramie River canyon) to large north- and south-oriented floods that converged in the Laramie Basin with the water escaping by eroding an east-oriented diverging and con- 
verging valley complex into what must have been a rising Laramie Mountains range so as to reach what at that time was an actively eroding southeast-oriented North Platte River valley head.

The Medicine Bow River ( $\mathrm{M}$ in Figure 1) begins in the Snowy Range, just to the north of Medicine Bow Peak and flows in a north direction down the Medicine Bow Mountains northern flank before turning in a northeast direction to reach the Laramie Basin western margin where it abruptly turns to flow in a west direction to join the north-oriented North Platte River. Rock Creek is an important Medicine Bow River tributary and begins in the Medicine Bow Mountains (to the east of the Snowy Range) at an abandoned valley's northern end. South-oriented headwaters of the North Fork Little Laramie River drain the abandoned valley's south end and make a U-turn before joining the north-oriented Little Laramie River. Rock Creek flows in north, northwest, and northeast directions as it descends into the northwestern Laramie Basin where it also makes an abrupt turn to flow a northwest direction to join the Medicine Bow River (at the point where the Medicine Bow River turns to flow in a west direction). The west-oriented Medicine Bow River and Rock Creek segments are joined by southwest- and south-oriented tributaries linked by abandoned valleys (referred to as divide crossings) with the south-oriented North Laramie River headwaters valley and with the east-oriented Laramie River (and North Laramie River) anatomizing complex of bedrock-walled canyon complex and also with several north-oriented drainage routes now flowing completely across the northern Laramie Mountains to reach the east- and southeast-oriented North Platte River segment.

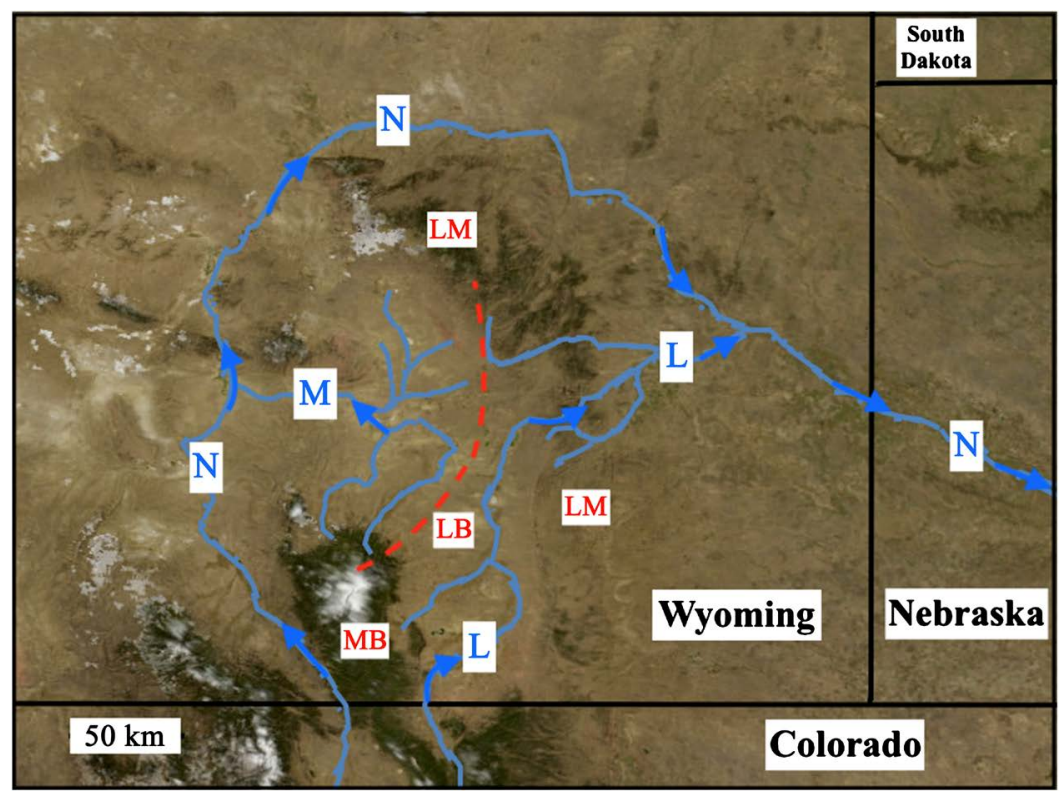

Figure 1. Modified imagery from the United States Geologic Survey Nation Map website showing the Medicine Bow-Laramie River drainage divide location (with a dashed red line) and major rivers (with arrows showing flow directions). Blue letters identify rivers and red letters identify mountains and basins as indicated in the text. 


\section{Research Method}

Prior to doing the study reported here many years were spent studying detailed topographic maps in effort to solve unsolved drainage history problems including two multiyear systematic investigations of detailed topographic maps covering the entire Missouri River drainage basin (in which the much smaller Medicine Bow and Laramie River drainage basins are located). More than 500 detailed research notes related to the second Missouri River drainage basin systematic study can be found in blog format at geomorphologyresearch.com. Research related to this paper used detailed topographic maps and tools available at the United States Geological Survey (USGS) National Map website to identify the Medicine Bow-Laramie River drainage divide and low points along the drainage divide (referred as divide crossings) where water could be interpreted to have flowed in one direction or the other across the present-day drainage divide. Each divide crossing was observed to link valleys draining in opposite directions to eventually reach either the Medicine Bow River or the Laramie River. The observed valleys were interpreted to have been used by water that once crossed the drainage divide and the opposing valleys were followed downstream to determine why the flow direction in one of the opposing valleys had been reversed so as to create the drainage divide. Present-day divide crossing elevations were noted and compared with elevations where the opposing valley drainage routes ultimately entered either the Medicine Bow or the Laramie Rivers.

Two fundamentally different hypotheses were used to interpret the map observations. The first hypothesis (referred to as the accepted paradigm) as described by Mears [13] begins with greater early Eocene mountain relief than today. During late Eocene, Oligocene, and early Miocene time the mountains were eroded and the intermontane basins (including the Laramie Basin) were filled with volcanic ash and eroded materials from the mountains so as to establish a low relief surface above which present-day mountain peaks stood as residual hills. Evidence supporting the interpretation that Oligocene and Miocene sediments once filled the Laramie Basin include isolated Oligocene deposits described by Evanoff [14] filling some Medicine Bow Mountain and Laramie Mountains valleys. Lillegraven and Ostresh [15] argue that during Oligocene and early Miocene time an east-oriented drainage system flowed across this low relief surface, although Knight [[16], p. 59] includes a diagram showing late Eocene north-oriented drainage in a mountain-surrounded Laramie Basin that turned to flow in a west direction. Regardless, regional uplift during the past 10 million years initiated massive erosion that exhumed what had been the early Eocene topography. Pelletier [17] attributes an increase in the intensity of snowmelt for the deep erosion that removed great thicknesses of the hypothesized Oligocene and early Miocene sediments from the southern Rocky Mountain intermontane basins (such as the Laramie Basin). While investigators disagree about many details the accepted paradigm general outline is commonly used even though geologic maps, such as Love and Christensen [18] Geologic Map of Wyoming, show 
the Laramie Basin today contains almost no traces of the Oligocene or Miocene sediments that supposedly once filled it.

The alternate and fundamentally different hypothesis (referred to as the new paradigm) requires all Missouri River drainage basin valleys (of any size) to have eroded headward across or along immense south- and southeast-oriented floods and forces recognition of a heavy (and probably thick) North American continental ice sheet (located where continental ice sheets are usually thought to have been located) which deeply eroded the underlying bedrock (the accepted paradigm does not recognize deep continental ice sheet erosion) and which caused crustal warping that raised entire regions and mountain ranges as massive melt water floods flowed across them (the accepted paradigm does not see a relationship between continental ice sheets and regional and mountain range uplift). From the new paradigm perspective Clausen [11] used converging north- and south-oriented floods, that spilled from the Laramie Basin across the rising Laramie Mountains to reach what was at the time an actively eroding southeast-oriented North Platte River valley head, to explain the east-oriented diverging and converging bedrock-walled canyon complex where the Laramie and North Laramie Rivers now cross the Laramie Mountains. From the same perspective Clausen [7] used headward erosion of the southeast-oriented North Platte River valley to explain unusual northern Laramie Mountain drainage routes. In addition, Clausen [9] explained how floodwaters that moved south on the present-day north-oriented Laramie and North Platte River alignments eroded what are today mountain passes across the Colorado continental divide before mountain uplift forced a Laramie River flow reversal which captured south-oriented floodwaters still moving on what is today the north-oriented North Platte River alignment.

\section{Results}

\subsection{Medicine Bow Mountains Divide Crossings}

Proceeding east and north from its southwest end along the Medicine Bow-Laramie River drainage divide a gap between Medicine Bow Peak and Browns Peak (number 1 in Figure 2) is the first of several divide crossings encountered. The gap floor elevation is about 3360 meters while Brown's Peak (east) rises to 3573 meters and Medicine Bow Peak (west) rises to 3652 meters. In a discussion of Medicine Bow Mountain glaciation Mears [19] points out the high Snowy Range ridge is composed of metasedimentary quartzite while the gap valley has been eroded in less resistant schist. The north-oriented Medicine Bow River begins immediately to the north of the gap and southeast-oriented Libby Creek drains the area to the south to an elevation of about 2530 meters where it joins the southeast-oriented North Fork Little Laramie River, which then makes a U-turn before joining (at an elevation of approximately 2357 meters) the northeast-oriented Little Laramie River (which eventually joins the north-oriented Laramie River at an elevation of about 2153 meters). However, an abandoned 


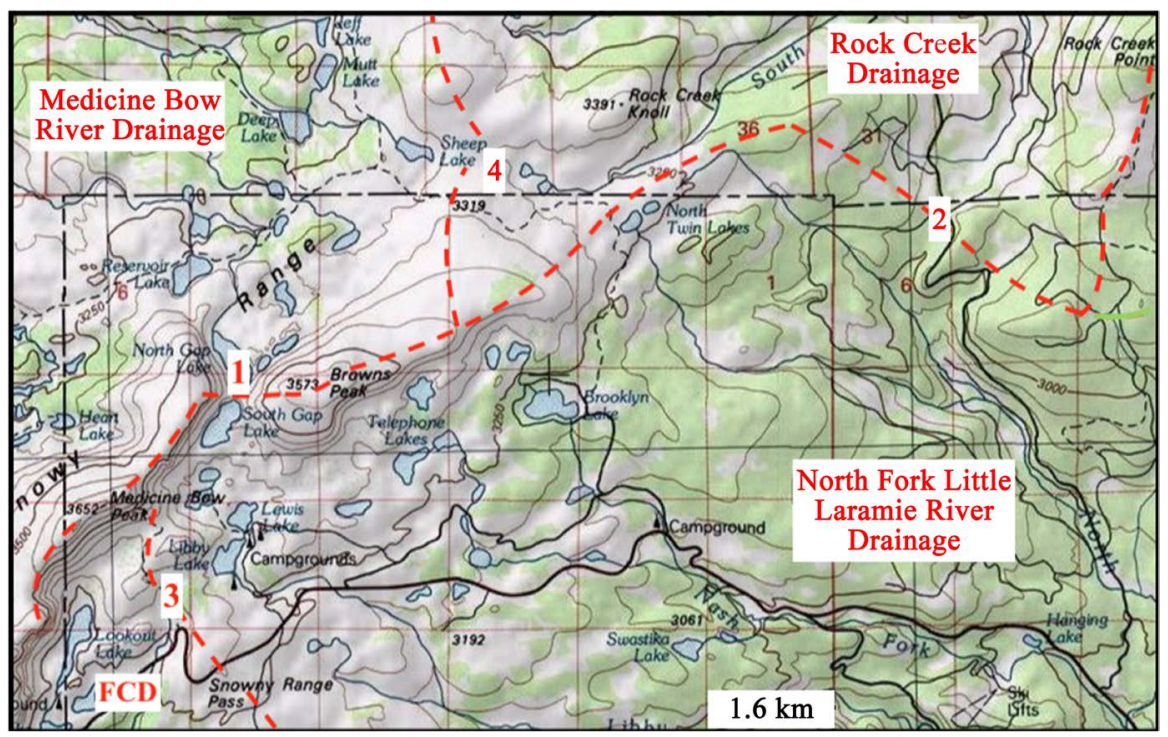

Figure 2. Modified topographic map from USGS National Map website showing Snowy Range drainage divides (red dashed lines) with red numbers showing divide crossing locations discussed in the text. FCD identifies south-oriented French Creek drainage flowing to the North Platte River. Contour interval is 50 meters.

valley (number 3 in Figure 2 with a floor elevation of about 3315 meters) leads from the Libby Creek headwaters to south-oriented South French Creek headwaters, which enter southwest-oriented French Creek (at an elevation of about 2378 meters), which at an elevation of approximately 2220 meters joins the north-oriented North Platte River. Water flowing in one direction or the other eroded the gap.

Numerous clues on the detailed topographic maps suggest a south-oriented drainage system once flowed across the Medicine Bow Mountains upland surface and to what are today north-oriented rivers. French Creek is one of many south-oriented (and barbed) tributaries flowing from the Medicine Bow Mountains to join the north-oriented North Platte River and the North Fork Little Laramie River U-turn is one of several drainage features suggesting south-oriented drainage from the Medicine Bow Mountains reversed its flow direction to address a Laramie Basin drainage direction reversal. Based on such topographic map evidence a large stream of water flowing in a south direction is interpreted to have eroded the 213-meter deep gap between Medicine Bow and Browns Peaks and to have split into diverging southeast- and southwest-oriented channels to erode the Libby Creek and South Fork French Creek valleys. But where did that water come from? Today the north-oriented Medicine Bow River descends on the Medicine Bow Mountains north slope to enter the Laramie Basin areas where elevations are less than 2100 meters and to have eroded the gap the water would have had to cross a quartzite ridge that today stands almost 1500 meters higher. Obviously when the gap was eroded the Snowy Range crest ridge did not stand higher than Laramie Basin floor as it does today.

A second major Medicine Bow-Laramie River drainage divide crossing is seen 
at number 2 (in Figure 2) and has an elevation of about 3033 meters and links north-oriented Rock Creek headwaters with south-oriented North Fork Little Laramie River headwaters. The previously mentioned North Fork Little Laramie River U-turn suggests south-oriented water once flowed along what is now the north-oriented Rock Creek headwaters alignment, although Rock Creek today descends more than 900 meters along the Medicine Bow Mountains northern slope to reach the Laramie Basin floor. To the north of Figure 2 the Medicine Bow-Laramie River drainage divide continues in a north direction on Rock Creek Ridge, which like Rock Creek descends towards the northwest Laramie Basin. Divide crossings along Rock Creek Ridge link east-oriented Laramie River tributary valleys with the deep north-oriented Rock Creek valley and provide evidence that water once flowed across Rock Creek Ridge. Whether that water was flowing toward or away from the present-day Rock Creek alignment could not be determined from the map evidence. Nor could it be determined whether those divide crossings had been eroded before or after flow on the Rock Creek alignment had been reversed to move in a north direction.

Perhaps even more intriguing and maybe easier to interpret are three high elevation divide crossings along the Medicine Bow River-Rock Creek drainage divide (the southern one is at number 4 in Figure 2 and the northern ones are to the north of the figure). The southern divide crossing has an elevation of about 3312 meters (48 meters lower than the gap floor) and links northeast-oriented South Fork Rock Creek (which joins Rock Creek at an elevation of about 2950 meters) with a northwest-oriented Medicine Bow River tributary. The next divide crossing to the north has a floor elevation of about 3250 meters (62 meters lower than the first divide crossing) and links northeast-oriented North Fork Rock Creek (which joins Rock Creek at an elevation of about 2740 meters) with the same northwest-oriented Medicine Bow River tributary. Further north a third divide crossing (floor elevation about 3178 meters and 72 meters lower than the second divide crossing) links northeast-oriented Deep Creek (which joins Rock Creek at an elevation of about 2645 meters) with the north-oriented Medicine Bow River valley.

When trying to interpret the three above described Medicine Bow River-Rock Creek drainage divide crossings regardless of paradigm being used it is assumed running water initially eroded all three divide crossings, although alpine glaciers may have altered some or all of the above described valleys and divide crossings. Nothing reported in the Mears [19] Medicine Bow Mountains glaciation discussion suggests otherwise. With that assumption from the accepted paradigm perspective the gap between Medicine Bow Peak and Browns Peak (number 1 in Figure 2) had to have been eroded prior to the Eocene as the Snowy Range now stands above the high-level Medicine Bow Mountains erosion surface, which the accepted paradigm interprets to correspond with the level of Oligocene and Miocene sediments hypothesized to have once filled the Laramie Basin and other intermontane basins. If so, it is difficult to explain why the north-oriented Medi- 
cine River originates to the north of the gap and why the diverging Libby Creek and South French Creek valleys originate to the south. And, if regional Miocene drainage had an eastward trend as some investigators suggest it is also difficult to explain why Rock Creek and Medicine Bow River headwaters now flow in north directions and why the North Fork Little Laramie River, Libby Creek, and South French Creek now flow in south directions. Further, the accepted paradigm provides no way to explain how water would erode three divide crossings at progressively lower elevations across the Medicine Bow River-Rock Creek drainage divide.

In contrast the new paradigm interprets the same features by use of immense south-oriented floods that flowed in complexes of diverging and converging channels across the region (as Medicine Bow Mountains uplift began). One flood flow channel followed what are today the north-oriented Rock Creek and south-oriented North Fork Little Laramie River (headwaters) alignment with the south oriented water converging with south-oriented flood flow on what is today the north-oriented Laramie River alignment. Another south-oriented flood flow channel followed what is today the north-oriented Medicine Bow River headwaters alignment and eroded the gap (between Medicine Bow and Browns Peaks) and then just south of the gap the channel diverged with one channel flowing in a southwest direction along the South French Creek alignment to join south-oriented flood flow on what is today the north-oriented North Platte River alignment while the other channel flowed in a southeast direction to join the south-oriented North Fork Little Laramie River headwaters. Eventually mountain uplift forced a reversal of flow on the Rock Creek alignment and south-oriented flood flow still moving on the Medicine Bow River headwaters alignment then made a U-turn so as to enter to the deeper and newly reversed Rock Creek valley. This first U-turn created the southwest end of the Medicine Bow-Laramie River drainage divide and eroded the divide crossing at number 4 (in Figure 2) and the northeast-oriented South Fork Rock Creek valley. As mountain uplift continued south-oriented flood flow on the Medicine Bow River headwaters alignment made its U-turn to reach the north-oriented Rock Creek valley at additional locations (each one north of the previous one), first along what is now the northeast-oriented North Fork Rock Creek alignment and later along the northeast-oriented Deep Creek alignment. Eventually mountain uplift reversed flow on the former south-oriented Medicine Bow River headwaters flood flow channel so as to create what is today the north-oriented Medicine Bow River headwaters valley.

\subsection{Laramie Mountains Divide Crossings}

The Medicine Bow-Laramie River drainage divide northern end is a triple drainage divide (at an elevation of 2631 meters) where it meets the southeast-oriented North Platte River drainage basin and is located in the Laramie Mountains just north of Figure 3 along the south-oriented North Laramie River 


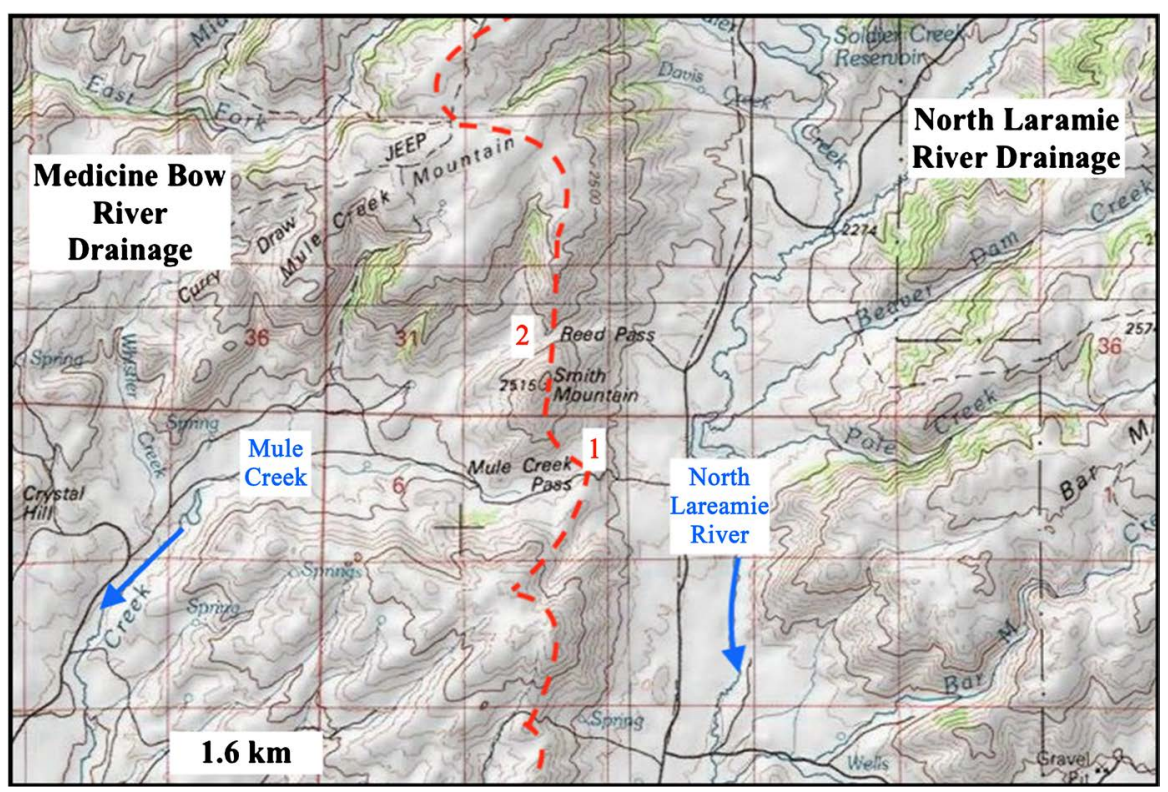

Figure 3. Modified topographic map from USGS National Map website showing Medicine Bow-Laramie River drainage divide (red dashed line) in Laramie Mountains. Red number 1 locates Mule Creek Pass and number 2 locates Reed Pass. Contour interval is 20 meters.

headwaters valley western rim. The North Laramie River flows in a southwest direction before entering its large south-oriented headwaters valley at an elevation of 2274 meters and flows as an underfit stream to enter the Laramie Basin northeast corner, where it immediately turns to cross the 2100-meter contour line and enter a northeast-oriented canyon to cross the Laramie Mountains and once on the Great Plains to join the Laramie River (at an elevation of 1369 meters). The south-oriented North Laramie River headwaters flow on the floor of what is now a north-to-south oriented through valley traceable on topographic maps completely across the Laramie Mountains. Today the through valley in the south is drained by the south-oriented North Laramie River headwaters, in the middle by various northeast-oriented North Platte River tributaries, and in the north by north-northeast oriented La Prele Creek. Oligocene and Miocene sediments partially fill the through valley north and south ends with Precambrian bedrock exposed in the middle. South of Figure 3 the Medicine Bow-Laramie River drainage divide before entering the Laramie Basin continues along the south-oriented North Laramie River valley western rim where several shallow divide crossing link the deeper south-oriented North Laramie River valley with southwest- and west-oriented Rogers Creek headwaters (flowing to southwest-oriented Sheep Creek and the Little Medicine Bow River).

The most obvious divide crossings along the Laramie Mountains segment of the Medicine Bow-Laramie River drainage divide are at Mule Creek Pass (number 1 in Figure 3) and at Reed Pass (number 2). The Mule Creek Pass floor elevation is 2323 meters and the pass links south-oriented North Laramie River headwaters with west- and south-oriented Mule Creek, which flows to south- 
west-oriented Sheep Creek, which in turn flows to the southwest-oriented Little Medicine Bow River (which flows to the west-oriented Medicine Bow River). The Mule Creek Pass floor is 60 meters higher than the North Laramie River and is 240 meters lower than a drainage divide high point located to the south. Reed Pass is approximately 120 meters deep and has a floor elevation of 2393 meters and is 70 meters higher than the Mule Creek Pass floor elevation and links the south-oriented North Laramie River valley with a southwest-oriented valley draining to west- and southwest-oriented Mule Creek. Between Mule Creek Pass and Reed Pass is Smith Mountain (elevation 2515 meters) and the west-oriented valleys on either side of Smith Mountain look on the map like hanging valleys that were cut off by the deeper south-oriented North Laramie River valley. However, the south-oriented North Laramie River headwaters valley is not a glacially carved valley, instead it is an oversized valley occupied by an underfit stream.

From both the accepted and the new paradigm perspectives Mule Creek Pass and Reed Pass record stream capture events, although the accepted paradigm interpretation sees Oligocene and Miocene sediments now in the North Laramie River headwaters as evidence the present-day drainage routes evolved on the surface of Oligocene and Miocene sediments that once buried (or at least partially buried) the Laramie Mountains. Such an interpretation can be used to explain the North Laramie River canyon crossing the Laramie Mountains and can even be used to explain the south-oriented North Laramie River headwaters valley location. However, that interpretation also requires headward erosion of the North Laramie River headwaters valley to have beheaded west-oriented streams flowing in 240- and 120-meter deep valleys, which according to Bishop [20] would be an unlikely event. Also, such an interpretation does not explain why the south-oriented North Laramie River headwaters valley is much larger than what the North Laramie River would be expected to erode. Nor does such an interpretation explain why the North Laramie River headwaters valley can be traced northward as a dismembered valley extending completely across the Laramie Mountains. In other words, while explaining some topographic map evidence the accepted paradigm does not explain all of the evidence.

The new paradigm interpretation requires large and prolonged south-oriented floods to have flowed in diverging and converging channels across the rising Laramie Mountains and into the Laramie Basin before southeast-oriented North Platte River valley headward erosion (combined with Laramie Mountains uplift) captured the flood flow. Laramie Mountains uplift occurred as the diverging and converging south-oriented flood flow channels carved valleys into the rising mountains, although some flood flow channels were more successful in keeping up with the mountain uplift than others. As a result, the more successful flood flow channels captured floodwaters from the less successful flood flow channels and Laramie Mountains drainage patterns today record what appear to be numerous stream capture events. At the same time the southeast-oriented North Platte River valley eroded headward from western Nebraska and captured in se- 
quence from east to west the south-oriented floodwaters. As North Platte River valley headward erosion proceeded along the developing Laramie Mountains northeast flank the south-oriented flood flow channels that had been moving floodwaters across the rising Laramie Mountains to the Laramie Basin were beheaded and reversed in sequence from east to west until south-oriented flood flow on the present-day north-oriented North Platte River segment was beheaded and reversed (regional uplift also greatly aided in that flow reversal process).

Before North Platte River valley headwater erosion beheaded and reversed south-oriented flood flow channels being carved into the rising Laramie Mountains the floodwaters had been flowing into the Laramie Basin where they had been met by north-oriented floodwaters that had flowed in a south direction to the west of the rising Medicine Bow Mountains and that had been forced by Colorado mountain uplift to make a U-turn around the Medicine Bow Mountains southern end (after a flow reversal on the Laramie River alignment). As a result, south-oriented floodwaters entering the Laramie Basin from the north were forced to flow in southwest and west directions. Trapped in the Laramie Basin the north-oriented floodwaters spilled eastward across the rising Laramie Mountains and carved a large complex of east-oriented diverging and converging bedrock-walled canyons. The northeast-oriented northern bedrock-walled canyon (today the North Laramie River canyon) was initiated as a southwest-oriented flood flow channel, but was beheaded and reversed by headward erosion of a deeper east-oriented valley (from what was then the actively eroding North Platte River valley). Once beheaded and reversed the northeast-oriented flow in what is now the North Laramie River canyon captured south-oriented flood flow moving into the eastern Laramie Basin and the deep south-oriented North Laramie River headwaters valley eroded headward into the rising Laramie Mountains to capture (and behead) what at that time were additional southwest-oriented flood flow channels (e.g. the Mule Creek valley). Headward erosion of the southeast-oriented North Platte River valley to the north then beheaded and reversed flow on the north end of that south-oriented flood flow channel (i.e. the south-oriented North Laramie River headwaters valley) which continuing Laramie Mountains uplift further dismembered. [While not determinable from topographic maps the new paradigm probably requires mapped Oligocene and Miocene sediments partially filling that valley to be flood deposited materials.]

\subsection{Laramie Basin Divide Crossings: Little Medicine Bow-North Laramie River Segment}

The Medicine Bow-Laramie River drainage divide in the Laramie Basin can be subdivided into two segments with the first being the between the North Laramie River and the Little Medicine Bow River. As already mentioned, the North Laramie River flows in a south direction to enter the Laramie Basin northeast corner where it turns and crosses the 2100-meter contour line as it enters the 
northeast-oriented North Laramie River canyon. Perhaps the most intriguing map evidence is at the north end of this drainage divide segment where previously mentioned Rogers Creek (which originated high on the west wall of the south-oriented North Laramie River valley to the south of Figure 3 and which is flowing as an intermittent stream to Sheep Creek, which then flows to the Little Medicine Bow River) and an unnamed southwest- and southeast-oriented intermittent stream (which enters southeast-oriented Twentytwo Mile Draw which drains to the North Laramie River) flow parallel to each other at an elevation of about 2174 meters and about 450 meters apart with the drainage divide between them in places being only about 2 meters high. Such a situation is almost impossible to explain if the North Laramie River route was established on a cover of Oligocene and Miocene sediments that had buried the Laramie Mountains. However the situation is easily explained by headward erosion of a shallow southeast-oriented valley from the actively eroding North Laramie River valley to capture southwest-oriented flood flow that was still moving across what is now the south-oriented North Laramie River headwaters valley just prior to headward erosion of the North Laramie River valley, which captured (and beheaded) the southwest-oriented flood flow.

Continuing in a south direction along the Little Medicine Bow-North Laramie River drainage divide a broad (more than 5 kilometers) a shallow divide crossing is just to the southeast of Buck Point and links east-northeast and southeast-oriented Twentytwo Mile Draw drainage to the North Laramie River with southeast-oriented Bone Creek headwaters (which flow to southwest-oriented Greasewood Creek and then to the Little Medicine River). Elevations vary from place to-place along the divide crossing, but are in the 2170- to 2175-meter range. This segment of the drainage divide is asymmetric with a much steeper slopes leading into the Bone Creek drainage basin, which is generally 30- to 40-meters lower than into the Twentytwo Mile Draw drainage area to the northeast. The broad divide crossing and the asymmetric drainage divide suggest large sheets of water flowed in a southwest direction from what is now the North Laramie River valley to reach west-oriented Little Medicine Bow and Medicine Bow River segments. Further south the asymmetric drainage divide continues and appears to have been eroded by large sheets of southwest-oriented water moving from the North Laramie River valley across the northeast-oriented Twentymile Draw and Elk Horn Draw drainage basins to reach the southwest-oriented Greasewood Creek drainage basin and Greasewood Flats (which today includes several closed depressions while otherwise being in the Rock Creek drainage basin). Little Medicine Bow-North Laramie River drainage divide features are difficult to explain from the accepted paradigm perspective but are consistent with new paradigm predictions.

\subsection{Laramie Basin Divide Crossings: Rock Creek-Laramie River Segment}

Proceeding from north to south along the Rock Creek-Laramie River drainage 
divide one of the first significant divide crossing encountered is an abandoned valley linking southwest oriented Sevenmile Creek with northeast oriented Duck Creek (seen in Figure 4). Today Sevenmile Creek joins a northwest-oriented Rock Creek segment flowing to the west-oriented Medicine Bow River. Duck Creek makes a southeast- and then northeast-oriented jog before entering the east-oriented Duck Creek canyon. The Duck Creek canyon is one of many diverging and converging canyons crossing the Laramie Range and within the Laramie Range the east-oriented Laramie River canyon turns in a north direction to join the east-oriented Duck Creek canyon (which then becomes the Laramie River canyon). Other abandoned north- and northeast-oriented canyons link the east-oriented Duck Creek canyon with the northeast-oriented North Laramie River canyon. Orientations of secondary valleys seen in Figure 4 suggest southwest-oriented water eroded the Sevenmile-Duck Creek through valley, which from the accepted paradigm perspective is difficult to explain, but which is consistent with previously described new paradigm interpretations of Little Medicine Bow-North Laramie River drainage divide features. However, the new paradigm interpretation requires at least some of the diverging and converging canyons now crossing the Laramie Range, including the northeast-oriented North Laramie River canyon, to have been initiated by southwest- and south-oriented flood flow channels which headward erosion of much deeper east-oriented valleys then beheaded and reversed.

Rock Creek flows a northeast direction where it emerges from the Medicine Bow Mountains onto the Laramie Basin floor and crosses the 2100-meter contour line and enters a narrower valley before continuing to its easternmost point where it makes a U-turn to flow in a northwest direction to join the west-oriented Medicine Bow River (at the point where the Medicine Bow River

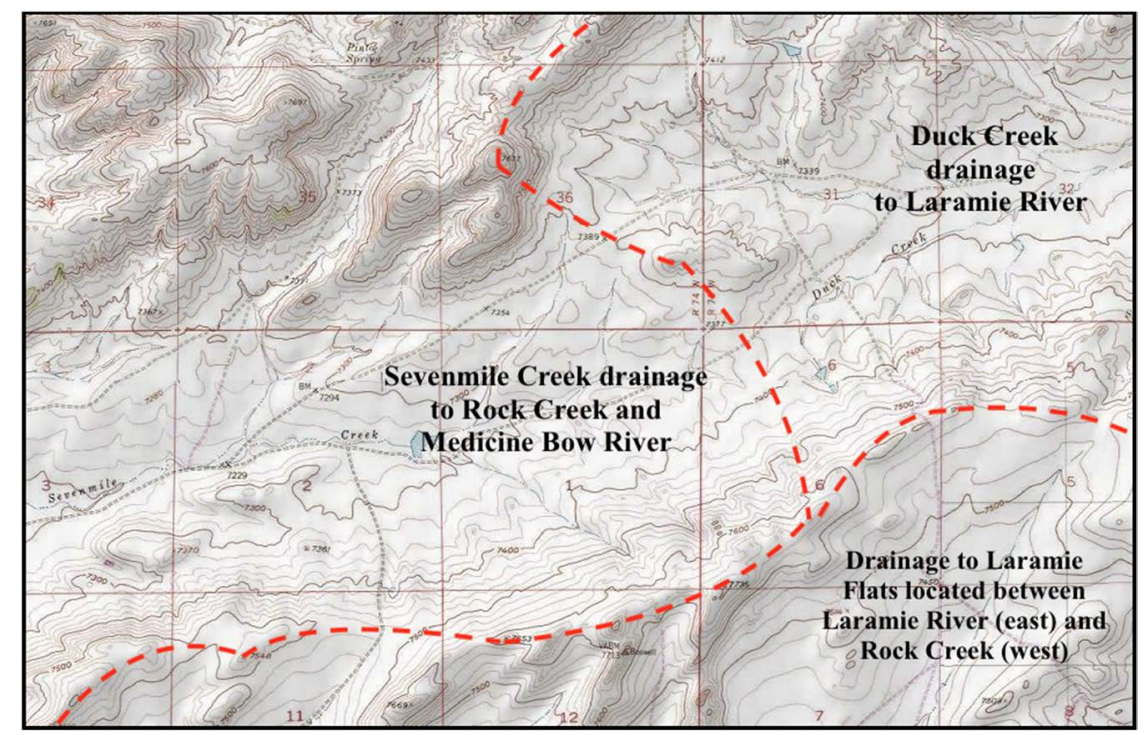

Figure 4. Modified topographic map from the USGS National Map website showing the abandoned valley linking the opposing Sevenmile and Duck Creek headwaters. Contour interval is 20 feet (6 meters). Sides of grid squares are 1.6 kilometers in length. 
turns in a west direction). At its easternmost point Rock Creek has an elevation of about 2042 meters and is about 16 kilometers west of the north-oriented Laramie River, which ten kilometers further north turns in an east direction to cross the 2100-meter contour line and enter a canyon to cross the Laramie Mountains. Between the Rock Creek easternmost point and the Laramie River is broad low relief surface (with some shallow closed depressions) where elevations are in the 2100- to 2150-meter range. About 8 kilometers to the east of that broad low relief surface (sometimes referred to as Laramie Flats) is the Laramie Mountains western flank and several entrances to the extensive Laramie Mountains diverging and converging bedrock-walled canyon complex, including the East and West Bluegrass Creek canyons, Halleck Canyon, and the Plumbago Creek valley (leading to the Sybille Creek Canyon) all of which are comparable in elevation to the broad low relief surface's elevation (and not much higher than the Laramie River elevation, which is higher than the Rock Creek elevation). The accepted paradigm provides no way to explain the Laramie Mountains diverging and converging bedrock-walled canyon complex, which may be why many previous investigators fail to mention the North Laramie River and Sybille Creek canyons and even if they do the Duck Creek Canyon, East and West Bluegrass Creek Canyons, and Halleck Canyon are seldom mentioned.

From the new paradigm perspective south-oriented floodwaters from the north once flowed across the Laramie Basin to reach the actively eroding south- and southwest-oriented Colorado River valley and lowered the Laramie Basin floor to a level below the basin floor elevations to the north of the Medicine Bow Mountains. For this reason, as Medicine Bow Mountain uplift began south-oriented flood flow continued on what is now the north-oriented Medicine Bow River headwaters alignment after flow on the Rock Creek headwaters alignment had been reversed to flow in a north direction into lower elevation Laramie Basin areas. This situation meant those south-oriented floodwaters on the Medicine Bow River headwaters alignment made a U-turn in what is today the high Medicine Bow Mountains to enter the newly reversed (north-oriented) Rock Creek valley and upon entering the Laramie Basin made a second U-turn to flow in a south direction. However, regional and mountain uplift reversed flow on the Medicine Bow River headwaters alignment and in the Laramie Basin, although south-oriented floodwaters then were still moving on what is today the north-oriented North Platte River alignment and making a U-turn in northern Colorado so as to enter the Laramie Basin. The result was the converging floodwaters were trapped in the Laramie Basin and spilled in whatever direction they could flow. The north-oriented floodwaters spilled eastward across the rising Laramie Mountains to carve the diverging and converging bedrock-walled canyon complex while most of the south-oriented floodwaters spilled westward (to the north of the rising Medicine Bow Mountains) and the west-oriented floodwaters captured the then greatly reduced north-oriented Rock Creek flow (the North Laramie River canyon also captured some south-oriented flow). Even- 
tually headward erosion of the southeast-oriented North Platte River valley ended all south-oriented flood flow and reversed flow on what is today the north-oriented North Platte River alignment and ended all north-oriented flood flow into the Laramie Basin.

To complete the Rock Creek-Laramie River drainage divide description Rock Creek on the Medicine Bow Mountains northern flank just before entering the Laramie Basin turns in northwest, north, and northeast directions and crosses the 2300-meter contour line to spread out on what might be a pediment surface. That surface is lower than surfaces on either side (especially on the west side) suggesting higher-level pediment surfaces once existed. Threemile Creek is a north-oriented stream joining Rock Creek in the Laramie Basin and on the Medicine Bow Mountains north slope a 100-meter deep abandoned valley links its headwaters valley with the northwest-oriented Rock Creek valley segment. About 3 kilometers upstream from that abandoned valley, where Rock Creek turns from flowing in a north direction to flow in a northwest direction, a 50-meter deep abandoned valley links the 200- to 300-meter deep north-oriented Rock Creek valley with the north-northeast oriented West Fork Dutton Creek valley, which further downstream is linked by an 80-meter deep abandoned valley with the north-oriented Threemile Creek valley at the point where West Fork Dutton Creek turns to flow in east direction to enter the Laramie Basin and to join northeast-oriented Dutton Creek, which flows to the Laramie River. These and similar creek direction changes and abandoned valleys on the lower Medicine Bow Mountains north slope suggest that as Medicine Bow Mountains uplift began Rock Creek was flowing in north-oriented diverging and converging valleys and headward erosion of the east-oriented West Fork Dutton Creek valley from the Laramie Basin captured the easternmost of these diverging and converging valleys before deeper erosion in the Rock Creek valley beheaded flow to that diverging valley.

\section{Conclusion}

Regardless of the paradigm being used laboratory experiments and numerical models and simulations do not even come close to describing how natural drainage divides such as the Medicine Bow-Laramie River drainage divide originate and evolve. Researchers wanting to understand drainage divide formation need to look at drainage divides as those drainage divides actually exist. To understand actual drainage divides any researcher willing to look can use detailed topographic maps available at the USGS National Map website to analyze drainage divides throughout the United States. The Medicine Bow-Laramie River drainage divide is not unique and is probably typical of many other actual drainage divides. Divide crossings along actual drainage divides are common and record numerous capture events, just as divide crossings along the Medicine Bow-Laramie River drainage divide record capture events. In most cases, just like in the Medicine Bow-Laramie River drainage divide example, the accepted paradigm is unable to 
explain many of the easy to document capture events that took place. A new and fundamentally different paradigm is needed in which drainage divide formation took place as massive floods flowed across rising regions and mountain ranges and requires recognition of a North American continental ice sheet that not only deeply eroded bedrock underneath it, but that also raised entire regions and mountain ranges as large and prolonged meltwater floods moved across them.

\section{Acknowledgements}

Arthur Strahler (then at Columbia University) and Brainerd Mears Jr. (then at the University of Wyoming) during the mid 1960s introduced this author to numerous unsolved drainage history problems. Preliminary work leading up to this paper was done while employed as a faculty member at Minot State University (North Dakota) where other faculty members, students, and library staff members greatly assisted in providing access to needed topographic maps.

\section{Conflicts of Interest}

The author declares no conflicts of interest regarding the publication of this paper.

\section{References}

[1] Bonnet, S. (2009) Shrinking and Splitting of Drainage Basins in Orogenic Landscapes from the Migration of the Main Drainage Divide. Nature Geoscience, 2, 766-771. https://doi.org/10.1038/ngeo666

[2] Spotila, J.A. (2012) Influence of Drainage Divide Structure on the Distribution of Mountain Peaks. Geology, 40, 855-858. https://doi.org/10.1130/G33338.1

[3] Mears Jr., B. (1991) Laramie Basin. In: Reheis, M.C., Palmquist, R.C., Agard, S.S., Jaworowski, C., Mears Jr., B., Madole, R.F., Nelson, A.R. and Osborn, G.D., Quaternary History of Some Southern and Central Rocky Mountain Basins: Chapter 14. In: Morrison, R.B., Ed., Quaternary Nonglacial Geology, Conterminous U.S., The Geology of North America, Vol. K-2. Geological Society of America, Boulder, CO, 418-427.

[4] Whipple, K.X., Forte, A.M., DiBase, R.A., Gasparini, N.M. and Ouimet, W.B. (2016) Timescales of Landscape Response to Divide Migration and Drainage Capture: Implications for the Role of Mobility in Landscape Evolution. Journal of Geophysical Research Earth Science, 122, 248-273. https://doi.org/10.1002/2016JF003973

[5] Pelletier, J.D. (2004) Persistent Drainage Migration in a Numerical Landscape Evolution Model. Geophysical Research Letters, 31, L20501. https://doi.org/10.1029/2004GL020802

[6] Scherler, D. and Schwanghart, W. (2020) Drainage Divide Networks Part 2: Response to Perturbations. Earth Surface Dynamics, 8, 261-274. https://doi.org/10.5194/esurf-8-261-2020

[7] Clausen, E. (2019) Use of Stream and Dismembered Stream Valleys Now Crossing Wyoming's Northern Laramie Mountains to Test a Recently Proposed Regional Geomorphology Paradigm, USA. Open Journal of Geology, 9, 731-751. https://doi.org/10.4236/ojg.2019.911087

[8] Bolyard, D.W. (1997) Late Cenozoic History of the Northern Colorado Front 
Range. In: Bolyard, D.W. and Sonnenberg, S.A., Eds., Geologic History of the Colorado Front Range, Rocky Mountain Association of Geologists, Denver, 125-134.

[9] Clausen, E. (2020) Topographic Map Analysis of Mountain Passes Crossing the Continental Divide between Colorado River Headwaters and North and South Platte River Headwaters to Test a New Geomorphology Paradigm, Colorado, USA. Journal of Geography and Geology, 12, 50-64. https://doi.org/10.5539/jgg.v12n1p50

[10] McCallum, M.E. (1968) Cenozoic History of the East-Central Medicine Bow Mountains. The Mountain Geologist, 5, 69-81.

[11] Clausen, E. (2018) Topographic Map Analysis of Laramie Range Bedrock-Walled Canyon Complex and the Goshen Hole Escarpment-Surrounded Basin, Albany and Platte Counties, Southeast Wyoming, USA. Open Journal of Geology, 8, 33-55. https://doi.org/10.4236/ojg.2018.81003

[12] Eckerle, W.P. (1986) Laramie to Walcott Junction. In: A Geologic Tour of Wyoming from Laramie to Lander, Jackson and Rock Springs, The Geological Survey of Wyoming Public Information Circular Number 27, 6-12.

[13] Mears Jr., B. (1993) Geomorphic History of Wyoming and High-Level Erosion Surfaces. In: Snoke, A.W., et al., Eds., Geology of Wyoming, Geological Survey Wyoming, Memoir 5, 608-626.

[14] Evanoff, E. (1990) Early Oligocene Paleovalleys in Southern and Central Wyoming: Evidence of High Local Relief on the Late Eocene Unconformity. Geology, 18, 443-446. https://doi.org/10.1130/0091-7613(1990)018<0443:EOPISA >2.3.CO;2

[15] Lillegraven, J.A. and Ostresh, L.J. (1988) Evolution of Wyoming's Early Cenozoic Topography and Drainage Patterns. National Geographic Research, 4, 303-327.

[16] Knight, S.H. (1990) Illustrated Geologic History of the Medicine Bow Mountains and Adjacent Areas, Wyoming. The Geologic Survey of Wyoming Memoir 4. 66 p.

[17] Pelletier, J.D. (2009) The Impact of Snowmelt on the Late Cenozoic Landscape of the Southern Rocky Mountains, USA. GSA Today, 19, 4-11.

https://doi.org/10.1130/GSATG44A.1

[18] Love, J.D. and Christiansen, A.C. (1985) Geologic Map of Wyoming. United States Geologic Survey, Wyoming State Geological Survey 2014 Release.

[19] Mears Jr., B. (2001) Glacial Records in the Medicine Bow Mountains and Sierra Madre of Southern Wyoming and Adjacent Colorado, with a Traveler's Guide to Their Sites. Wyoming State Geological Survey Public Information Circular No. 11, $26 \mathrm{p}$.

[20] Bishop, P. (1995) Drainage Rearrangement by River Capture, Beheading and Diversion. Progress in Physical Geography, 19, 449-473.

https://doi.org/10.1177/030913339501900402 